\title{
The Entrepreneurial University: Conceptualisation, Models and Challenges for Operationalisation of the Concept
}

\author{
Ewa Badzińska iD \\ Poznan University of Technology
}

\section{Introduction}

Higher education is facing growing challenges in the definition of its purpose, basic and applied research, flexible organization as well as its responsibility for the development of society, the environment and the economy. The information and communication technology revolution, the emergence of the knowledge economy, significant challenges like big data, the Internet of things, artificial intelligence and the industrial development 4.0 have all shed new light and have imposed new demands on higher education systems across the world.

Audretsch ${ }^{1}$ emphasises that the forces shaping economic growth and performance also influence the corresponding role for the university. One significant response to the challenges of the higher education system is seen in the creation and development of an Entrepreneurial University which brings together internal and external stakeholders to look for mutual cooperation mechanism to facilitate and accelerate knowledge spillover and absorption of innovative solutions in society and the economy. Part of this response is the development of academic fields and areas of research that are not just focused on "knowledge for its own sake", but rather oriented towards knowledge for solving specific and compelling problems as well as challenges confronting societ ${ }^{2}$.

1 D.B. Audretsch, From the entrepreneurial university to the university for the entrepreneurial society, "The Journal of Technology Transfer" 2014, vol. 39, pp. 313-321.

2 Ibidem, p. 317. 
According to Drucker ${ }^{3}$, the generation of an entrepreneurial process in public institutions requires four elements: clear definition of missions, a realistic statement of obtainable goals, failure to archive objectives and constantly strive for innovation opportunity. In the 21st century, the entrepreneurial mission appears as a result of the collapse produced by the inevitable production of research results with practical implications and the external demand of greater utility from public findings ${ }^{4}$. In response to the demand of different stakeholders an effective cooperation between universities, governance, and a business ecosystem is required for sustainable development.

The current changes in the surrounding environment require new competences and new ways of teaching and learning. "Creating widespread awareness amongst staff and students of the importance of developing a range of entrepreneurial abilities and skills is therefore an important function of an Entrepreneurial University"5. The need for skillful and multicultural competent graduates with an entrepreneurial and intrapreneurial mindset is crucial. Universities need to cooperate widely to be able to renew their curricula and practices responding to the challenges in order to foster more competitive and innovative economies. "Moreover, definitely, the need for the competence development is relevant in any field of higher education - it includes much more than business or economics: the need is multi-sectoral and multidisciplinary as the working life itself"6.

In addition, higher education institutions are expected to benefit the regions in many different ways, not only by educating competent graduates, but also by actively promoting regional development and competitiveness. The university is expected to fulfill its obligations related with research, teaching and entrepreneurial mission ${ }^{7}$ for creating and fostering new products and processes. For this reason, universities look for ways to build entrepreneurial pathways and create internationalisation opportunities for students and staff. Therefore, a lot of attention is paid to the development of student-oriented participatory teaching and sharing

3 P.F. Drucker, Innovation and Entrepreneurship, Harper and Row, New York 1985.

4 H. Etzkowitz, The evolution of the entrepreneurial University, "International Journal of Technology and Globalisation" 2004, vol. 1(1), pp. 64-77.

5 OECD, A Guiding Framework for Entrepreneurial Universities, 2012, p. 10, https://www.oe cd.org/site/cfecpr/EC-OECD\%20Entrepreneurial\%20Universities\%20Framework.pdf (accessed: 18.10.2019).

6 L. Timonen, E. Badzinska, H. Immonen, How to build entrepreneurial pathways for students? - Reflections on development cases from Karelia University of Applied Sciences, Finland, and Poznan University of Technology, Poland, Working Paper, International Conference CREE2019 Entrepreneurship Education, Roanne, March 2019, p. 3.

7 H. Etzkowitz, The evolution... 
with peers ${ }^{8}$. In this context, the analysis of entrepreneurship within the university curricula and entrepreneurship training programmes has attracted the interest of many researchers ${ }^{9}$. Universities have incorporated entrepreneurial educational programmes in undergraduate, master and doctoral educational levels. There are many approaches to delivering entrepreneurial learning which can be adopted throughout a university. As internationalisation is increasingly integrated into the strategic processes of higher education institutions, it has become essential for universities to be able to enhance performance in international activities.

This explorative study aims to review the approaches of scholars to the concept of an Entrepreneurial University based on in-depth, critical analysis of the subject literature. The study attempts to adapt existing models and bring new factors together with current reflections on this phenomenon. The author's contribution consists of developing a framework of preconditions - endo- and exogenous factors within the entrepreneurial ecosystem and micro- and macroeconomic environment - necessary to transform a traditional university into the Entrepreneurial University. In this perception, the author identifies the limitations, ambiguities and difficulties with the operationalisation of significant factors, variables and their measurement.

The methods used to reach this objective are a critical review of the subject literature, defining, comparing, factors analysis, reflection, and inference. The conceptual discussion benefits (among other studies) from the works by Guerrero-Cano,

8 E. Badzińska, L. Timonen, Entrepreneurial Mindset and Muliticultural Communication Skills: a Reflection on the ECMT+Intensive Programme, "Zeszyty Naukowe Politechniki Poznańskiej", serie "Organizacja i Zarządzanie" 2019, no. 79, pp. 5-19.

9 A. Gibb, Towards the Entrepreneurial University. Entrepreneurship Education as a lever for change, NCGE UK Policy Paper series, 2005; J. Guzmán, F. Liñán, Perspectives on Entrepreneurial Education: A US Europe Comparison, Universidad Antionio de Nebrija, Madrid 2005; K. Wach, Entrepreneurship Education in Poland, "ERENET Profile" 2008, vol. III, no. 3(11), pp. 36-44; S. Kurek, T. Rachwat, The Role of Business Education in the Development of Entrepreneurship in the Member States of the European Union, "Europa XXI" 2010, vol. 19, pp. 127-142; M. Raposo, A. Paço, Entrepreneurship Education: Relationship between Education and Entrepreneurial Activity, "Psicothema" 2011, vol. 23(3), pp. 453-457; K. Wach, Europeanisation of Entrepreneurship Education in Europe - Looking Back and Looking Forward, "Horyzonty Wychowania" 2014, vol. 13(26), pp. 11-31; A. Fayolle, B. Gailly, The Impact of Entrepreneurship Education on Entrepreneurial Attitudes and Intention: Hysteresis and Persistence, "Journal of Small Business Management" 2015, vol. 53, pp. 75-93; A. Żur, Exploring the Role of Inspiration in Entrepreneurship Education, "Horyzonty Wychowania” 2014, vol. 13(26), pp. 179-194; T. Rachwat, S. Kurek, M. Boguś, Entrepreneurship Education at Secondary Level in Transition Economies: A Case of Poland, "Entrepreneurial Business and Economics Review" 2016, vol. 4(1), pp. 61-81. 
Kirby, and Urbano ${ }^{10}$, Audretsch ${ }^{11}$ and A Guiding Framework for Entrepreneurial Universities $^{12}$ that provide an understandable context of the main factors affecting the creation and development of Entrepreneurial Universities. The nature of the study is descriptive and reflective, and it provides an illustration of the concept of an Entrepreneurial University stressing the difficulties associated with the evaluation of the achieved state.

This paper is composed of the following four parts: (i) literature review on the concept of the Entrepreneurial University, (ii) theoretical models and a framework of factors affecting the transformation into an Entrepreneurial University, (iii) challenges for operationalisation and measurement of factors and study limitations, (iv) conclusions and future research lines.

\section{The Entrepreneurial University - Conceptualisation}

The term "Entrepreneurial University" was used by Etzkowitz ${ }^{13}$ to describe those universities that improved different mechanism by their scientists to contribute to the regional development and increase their incomes; they are considering new sources of funds like patents, conducting research under contracts and entry into a partnership with a private enterprise.

It was argued that, in terms of organization, Entrepreneurial Universities are managed in such a way that they become capable of responding flexibly, strategically and autonomously to opportunities and challenges in the environment. Clark $^{14}$ describes this as having a strong steering core with acceptance of a model of self-made autonomy across the academic departments. Furthermore, an Entrepreneurial University seeks to develop/undertake a substantial shift in organizational character to achieve a more promising position for the future and become a significant actor in their own terms. Moreover, an Entrepreneurial University has a vision oriented towards quality, adaptation and entrepreneurial culture.

10 M. Guerrero-Cano, D. Kirby, D. Urbano, A literature review on entrepreneurial universities: An institutional approach, Working paper presented at the 3rd Conference of Pre-communications to Congresses, Business Economic Department, Autonomous University of Barcelona, Barcelona, June 2006.

11 D.B. Audretsch, From the entrepreneurial university...

12 OECD, A Guiding Framework...

13 H. Etzkowitz, Entrepreneurial Scientists and Entrepreneurial Universities in American Academic Science, "Minerva" 1983, vol. 21(2-3), pp. 198-233.

14 B.R. Clark, Creating Entrepreneurial Universities. Organisational pathways of transformation, Pergamon IAU Press, Oxford 1998. 
In addition, Clark $^{15}$ states that universities are entrepreneurial when they are unafraid to maximise the potential for commercialisation of their ideas and create value in society and do not see this as a significant threat to academic values.

In turn, Kirby ${ }^{16}$ emphasizes that Entrepreneurial Universities have the ability to innovate, recognize and create opportunities, work in teams, take risks and respond to challenges. In this context, Etzkowitz ${ }^{17}$ even considers that the Entrepreneurial University is a natural incubator providing support structures for teachers and students to initiate new ventures: intellectual, commercial and conjoint. Already before Etzkowitz and Leydesdorff ${ }^{18}$ underlined the requirement to shift towards a Triple Helix model of partnership between government, industry and higher education to strengthen the dynamics of innovation.

According to Audretsch ${ }^{19}$, the core of the university remains the basic disciplines, fields and academic traditions however, an additional academic activity has been extended to teaching and application research with the primary focus on providing solutions and implementations to major problems, interests and demands confronting society or particular aspects of society. In order to facilitate technology transfer and generate sufficient knowledge spillover from the university for commercialization, innovation and economic growth, absorbative capacity mechanism in the environment is necessary ${ }^{20}$. The relevance and applicability of the knowledge created at an Entrepreneurial University has become a key value in these new, practise-oriented fields and areas of research, such as biochemistry, informatics, and bioengineering.

The new approach to the role of universities as a driving force for entrepreneurship development in the wider regional, social and community environment envisages a structural shift from their traditional missions to a third task: the commercialization of new knowledge in the form of patents, licences, and university-sanctioned start-ups for economic development ${ }^{21}$. In addition, to facilitate the

15 B.R. Clark, Sustaining Change in Universities: Continuities in case studies and concepts, Society for Research into Higher Education and Open University Press, New York 2004.

16 D.A. Kirby, Creating Entrepreneurial Universities: A Consideration, Working Paper, School of Management, University of Surrey, 2002.

17 H. Etzkowitz, Research groups as 'quasi firms': the invention of the entrepreneurial university, "Research Policy" 2003, vol. 32, pp. 109-121.

$18 \mathrm{H}$. Etzkowitz, L. Leydesdorff, The dynamics of innovation: from the National Systems and "Mode 2" to a Triple Helix of university-industry-government relations, "Research Policy" 2000, vol. 29, pp. 109-123.

19 D.B. Audretsch, From the entrepreneurial university...

20 Ibidem, pp. 317-318.

$21 \mathrm{H}$. Etzkowitz et al., The future of the University and the University of the future: Evolution of ivory tower to entrepreneurial paradigm, "Research Policy" 2000, vol. 29(2), pp. 313-330. 
generation and commercialization of university research and help start new ventures, an Entrepreneurial University has not only to change its core activities and routines, but also combine adequate organizational environments and resources ${ }^{22}$. "Integrating a university's mission for economic and social development urges universities towards transformation of traditional teaching and research universities towards entrepreneurial universities" 23 . It is even claimed that the university should transform to the university for the entrepreneurial society. While an Entrepreneurial University is a response to generate and transfer technology and knowledge-based start-ups, "the role of the university in the entrepreneurial society has broadened to focus on enhancing entrepreneurship capital and facilitating behaviour to prosper in an entrepreneurial society" 24 .

Great emphasis is placed on the need for high flexibility of the university in its response to the environmental requirements. In this context, Gibb, Haskins, and Robertson ${ }^{25}$ propose a changing university paradigm from pure knowledge and research-based paradigm to pure value relevance, integrated and engaged embedded in high levels of uncertainty and complexity. Nowadays, a crucial challenge of the higher educational system is to create favourable preconditions to prepare students for the modern business world and practices in multicultural teams. For the above reasons, universities have to understand the value of multiple stakeholder engagement to support entrepreneurship and therefore be involved in a range of partnerships within the business ecosystem that stimulates the process of technological entrepreneurship ${ }^{26}$. Thus, universities are facing difficult challenges that require them to rethink their business models and become more entrepreneurial ${ }^{27}$.

The literature review does not show consensus for one common definition of an Entrepreneurial University however, several important characteristics are indicated that reveal the importance of internal and external factors that strongly influence this type of university, namely: high interdependence with the government and

22 M. Guerrero, D. Urbano, The Creation and Development of Entrepreneurial Universities in Spain: An Institutional Approach, Nova Publishers, New York 2011.

23 D. Arnaut, R. Dogić, The Inevitability of University Entrepreneurial Path, [in:] V. Babić (ed.), Contemporary Issues in Economics Business and Management, Faculty of Economics University of Kragujevac, Kragujevac 2018, p. 70.

24 D.B. Audretsch, From the entrepreneurial university..., p. 313.

25 A. Gibb, G. Haskins, I. Robertson, Leading the Entrepreneurial University. Meeting the entrepreneurial development needs of higher education institutions, NCGE UK, Birmingham 2009.

26 E. Badzińska, The Concept of Technological Entrepreneurship: The Example of Business Implementation, "Entrepreneurial Business and Economics Review" 2016, vol. 4(3), pp. 55-70.

27 M. McAdam, K. Miller, R. McAdam, University business models in disequilibrium - engaging industry and end users within university technology transfer processes, "R\&D Management" 2017, vol. 47(13), pp. 458-472. 
industry firms, different sources of funding, entrepreneurial activities of all community members (students, academic, alumni), implementation of different strategies to accelerate knowledge spillover and improve the creation of new ventures, as well as the adjustments in the organizational structure of universities. In addition, some definitions express a process that goes on inside an existing higher education institution and leads not only to new business ventures but also to other innovative activities such as the development of new products, services, technologies, strategies and competitive postures ${ }^{28}$.

\section{A framework for Entrepreneurial University - Theoretical Models}

In the subject literature there are identified various theoretical models associated with the creation and development of an Entrepreneurial University or even its transformation (selected ones are synthesized below). In each one, there are conditions and prerequisites associated with formal and informal factors as well as environmental factors.

One of the first approaches to characterize an Entrepreneurial University was that proposed by Clark in 1998. Using the case study method, he examined five European universities und observed common features, which he considered characteristic for the entrepreneurial transformation of these universities. Clark ${ }^{29}$ identified the five core elements/pathways of an institutional transformation to an Entrepreneurial University, namely: (i) strengthened steering core to embrace management groups and academics; (ii) an expanded developmental periphery involving a growth of units that reaches out beyond the traditional areas in the university; (iii) a diversified funding base, not only by use of government third stream funding but from a wide variety of sources; (iv) an integrated entrepreneurial culture defined in terms of common commitment to change; (v) a stimulated academic heartland with academics committed to the entrepreneurial concept.

In turn in 2000, Etzkowitz, Webster, Gebhardt and Cantisano ${ }^{30}$, examined and explained the development mechanism for the university of the future, and thus into the Entrepreneurial University. According to the authors, the transformation can be obtained through a formal process that consists of: (i) internal transformation including a revision of existing tasks; (ii) trans-institutional impact

28 B. Antoncic, R. Hisrich, Intrapreneurship: Construct refinement and cross-cultural validation, "Journal of Business Venturing" 2001, vol. 16, pp. 495-527.

29 B.R. Clark, Creating Entrepreneurial Universities...

30 H. Etzkowitz et al., The future of the University... 
with projects to achieve a stabilization; (iii) interface process of decentralization of the institution; (iv) recursive effects with the collaboration of trilateral organizations.

Afterwards, the Entrepreneurial University model was proposed by Etzkowitz in $2004^{31}$, which was a guideline for an institutional renovation that includes: (i) hybrid organizational forms; (ii) interdependence with industry and government; (iii) independence with other institutional spheres; (iv) capitalization of knowledge; (v) reflexivity involving continuous renewal of internal structures. In this transition, the change of governance was identified as a shift from state control to selfregulation of the universities with a supervising state as a consequence ${ }^{32}$. In other words, it is not a place for hierarchy and bureaucracy because a horizontal coordination is the better way to share intellectual, financial and physical resources ${ }^{33}$. "The higher autonomy and cooperation with the state, the greater the positive impact into an Entrepreneurial University"34.

Towards building adaptive universities, Sporn ${ }^{35}$ proposed a model focused on the external adaptation of higher education and the inter-related connection between the university structure and the surrounding environment using management, governance and leadership. The designed model includes the following factors: (i) mission and goals; (ii) the university structure; (iii) management, governance and leadership; (iv) organizational culture in the adaptation process; (v) networks and strategic alliances; (vi) embedding in the environment. In consequence, an entrepreneurial culture is the principal indicator to develop a new climate for innovation, individual responsibilities, change and a win-win situation for the institution and its faculties ${ }^{36}$.

Another noteworthy model is that created by Kirby ${ }^{37}$, which contains five formal factors (strategic actions) related with the organization and two informal factors related with its promotion and recognition. The identified factors are as follows: (i) incorporation; (ii) implementation; (iii) communication; (iv) organization;

31 H. Etzkowitz, The evolution...

32 B.R. Clark, The Higher Education System: Academic Organisation in Cross-national Perspective, University of California Press, Berkeley 1983.

33 F. Van Vught, Innovative Universities, "Tertiary Education and Management" 1999, vol. 5(4), pp. 347-354.

34 M. Guerrero-Cano, D. Kirby, D. Urbano, A literature review..., p. 13.

35 B. Sporn, Building Adaptive Universities: Emerging Organisational Forms Based on Experiences of European and US Universities, "Tertiary Education and Management" 2001, vol. 7(2), pp. 121-134.

36 Ibidem.

37 D.A. Kirby, Creating Entrepreneurial Universities in the UK: Applying entrepreneurship theory to practice, "Journal of Technology Transfer" 2006, vol. 31(5), pp. 599-603. 
(v) encouragement and suport; (vi) recognition and reward; (vii) endorsement; (viii) promotion.

Another interesting approach and a framework for Entrepreneurial Universities was presented by Guerrero-Cano, Urbano and Kirby in $2006^{38}$. The theoretical model considering the environmental dimension contains formal and informal factors that condition the creation and development of these type of universities. The elements associated with formal factors focus especially on: (i) the organizational structure and the university government; (ii) entrepreneurship education programmes; (iii) support measures to entrepreneurial activities. In turn, the informal factors relate to: (i) entrepreneurship teaching methodology; (ii) university attitudes towards entrepreneurship; (iii) role models and academic reward systems. Furthermore, the authors conclude that this type of university generates several direct outcomes, which follow the three university missions (teaching, research and entrepreneurial) proposed by Etzkowitz ${ }^{39}$.

For the present study, the endo- and exogenous factors considered as a framework for the transformation into an Entrepreneurial University are created and synthetically presented in the Table 1.

Table 1. Preconditions for the transformation into an Entrepreneurial University

\begin{tabular}{|c|c|}
\hline \multicolumn{2}{|c|}{ Endogenous Factors } \\
\hline Formal Factors & Informal Factors \\
\hline $\begin{array}{l}\text { Management and organizational structure } \\
\text { of the university: } \\
\text { - mission, vision, strategic management; } \\
\text { - internationalisation strategy, strategic } \\
\text { international partnerships; } \\
\text { - organizational structures - a shift from state } \\
\text { control to self-regulation of the university; } \\
\text { - independence, flexibility, self-government. }\end{array}$ & $\begin{array}{l}\text { Entrepreneurial community and } \\
\text { intellectual potential of the university: } \\
\text { - entrepreneurial mindsets and skills, } \\
\text { expertise and experience of academics, } \\
\text { visiting professors and inventors, students, } \\
\text { interns, alumni, cooperating business } \\
\text { practitioners and other enterprising } \\
\text { university employees; } \\
\text { - international networks, bilateral } \\
\text { partnerships (consortia, alliances) with } \\
\text { other international institutions. }\end{array}$ \\
\hline $\begin{array}{l}\text { University tangible resources and } \\
\text { entrepreneurship support measures: } \\
\text { - high technology infrastructure, research } \\
\text { facilities and IT services, laboratories, R\&D } \\
\text { department, business incubators to start- } \\
\text { up creation, technology and innovation } \\
\text { transfer centre, science park, career } \\
\text { counseling centre, student organizations, } \\
\text { others. }\end{array}$ & $\begin{array}{l}\text { Entrepreneurial culture at the university: } \\
\text { - attitude of the authorities and the } \\
\text { academic community to entrepreneurship } \\
\text { education and creation of start-ups/ } \\
\text { spin-offs; } \\
\text { - for commercialization of scientific research; } \\
\text { - knowledge and innovation management } \\
\text { processes at the organization level. }\end{array}$ \\
\hline
\end{tabular}

38 M. Guerrero-Cano, D. Kirby, D. Urbano, A literature review..., pp. 10-19.

39 H. Etzkowitz, The evolution... 
Table 1 (continued)

\begin{tabular}{|c|c|c|c|}
\hline \multicolumn{2}{|c|}{$\begin{array}{l}\text { University entrepreneurship education } \\
\text { programmes: } \\
\text { - doctoral, master programmes and } \\
\text { undergraduate courses in entrepreneurship } \\
\text { and transversal competences, practice- } \\
\text { oriented curricula; } \\
\text { - experiential learning approach, internships } \\
\text { in enterprises, dual education system; } \\
\text { - international mobility of staff and students; } \\
\text { - double degrees and international } \\
\text { partnerships. }\end{array}$} & \multicolumn{2}{|c|}{$\begin{array}{l}\text { University image and good practices: } \\
\text { - system of norms and values; } \\
\text { - tradition and experience, reputation; } \\
\text { - achievement evaluation criteria, academic } \\
\text { reword system, promoting successes } \\
\text { of students and graduates, academic } \\
\text { or other university employees. }\end{array}$} \\
\hline \multicolumn{4}{|c|}{ Exogenous Factors } \\
\hline Entrepreneurial Ecosystem & & $\begin{array}{l}\text { roeconomic } \\
\text { avironment }\end{array}$ & $\begin{array}{l}\text { Macroeconomic } \\
\text { Environment }\end{array}$ \\
\hline $\begin{array}{l}\text { Favourable environments } \\
\text { of interdependent actors and } \\
\text { resources which enable the } \\
\text { emergence of high growth } \\
\text { business activities through } \\
\text { specific policies and instruments: } \\
\text { business environment institutions, } \\
\text { R\&D centres, innovation and } \\
\text { business centres, consultancy, } \\
\text { organizational, funding and } \\
\text { infrastructure services, the public } \\
\text { sector supporting institutions, } \\
\text { business associations for } \\
\text { entrepreneurship, professional } \\
\text { bodies, local government chambers } \\
\text { of commerce. } \\
\text { Cooperation with selected } \\
\text { research institutions, universities } \\
\text { and other external stakeholders } \\
\text { supporting network for the } \\
\text { exchange of information, diffusion } \\
\text { of knowledge, implementation } \\
\text { of joint projects and dissemination } \\
\text { of best practices. } \\
\text { Consortia, networks and strategic } \\
\text { alliances, external relation- and } \\
\text { partnerships. }\end{array}$ & $\begin{array}{l}\text { Regional } \\
\text { financial } \\
\text { aspects a } \\
\text { institutio } \\
\text { business } \\
\text { interdepe } \\
\text { the gover } \\
\text { industry f } \\
\text { Distincti } \\
\text { condition } \\
\text { Organizat } \\
\text { to enviror } \\
\text { spatial m } \\
\text { Higher ed } \\
\text { institutio } \\
\text { governme }\end{array}$ & $\begin{array}{l}\text { socio-economic, } \\
\text { and cultural } \\
\text { nd policies; } \\
\text { nal and } \\
\text { environment; } \\
\text { endence with } \\
\text { nment and } \\
\text { firms. } \\
\text { ve sector, sectoral } \\
\text { is- mesoeconomic } \\
\text { dimension. } \\
\text { tional adaptation } \\
\text { nmental changes, } \\
\text { anagement. } \\
\text { ducation } \\
\text { ns and local } \\
\text { ent units. }\end{array}$ & $\begin{array}{l}\text { The economic, social, } \\
\text { political and institutional } \\
\text { context of the country. } \\
\text { Development of new } \\
\text { information and } \\
\text { communication } \\
\text { technologies and } \\
\text { infrastructure. } \\
\text { Regulations of the Ministry } \\
\text { of Higher Education, } \\
\text { government act, higher } \\
\text { education law, legal rules. }\end{array}$ \\
\hline
\end{tabular}

Source: own study (division in formal and informal factors adapted from M. Guerrero-Cano, D. Kirby, D. Urbano, A literature review on entrepreneurial universities: An institutional approach, Working paper presented at the 3rd Conference of Pre-communications to Congresses, Business Economic Department, Autonomous University of Barcelona, Barcelona, June 2006, p. 6.

All the above factors serve to shape changes in organization and management (governance) structures of universities which lead to the verification of mission 
statements and strategies. The aim is to become aware of the existence and functioning of the entrepreneurial ecosystem and facilities for the creation of entrepreneurial study pathways and international excellence. Noteworthy is the effective collaboration with research centres and the business-related sphere towards the acceleration of the knowledge spillover from universities, the development of applied research, and the appropriate adaptation of the obtained outcomes to the needs of society, environment, and the economy. A particularly important mechanism for knowledge exchange is staff and student mobility, which includes internships and programmes for teaching and research exchange. In this perception, the transformation of decision-making and leadership roles as well as responsibilities at the organizational level requires networks, strategic alliances, and joint projects for exploiting entrepreneurial opportunities with industry, the government and other higher education institutions.

Based on findings of various authors' publications from 1998 up to 2012, more specific characteristics of an Entrepreneurial University were developed under the aegis of the European Commission's DG Education and Culture, in collaboration with the OECD LEED forum, and supported by a panel of six independent experts in this field. As a result, A Guiding Framework for Entrepreneurial Universities was delivered in 2012. It is designed to help interested universities assess themselves against statements which are organised under the following seven areas: (i) Leadership and Governance; (ii) Organizational Capacity, People and Incentives; (iii) Entrepreneurship development in teaching and learning; (iv) Pathways for entrepreneurs; (v) University-Business/external relationships for knowledge exchange; (vi) The Entrepreneurial University as an international institution; (vii) Measuring the impact of the Entrepreneurial University.

The OECD framework can be used as a thematic reflection model where the above-mentioned statements are factors likely to be characteristic of an Entrepreneurial University. Several activities are proposed which are established and managed by a university in order to justify the status of an Entrepreneurial University 40 . The scheme is practical and visual, and it helps to organise the development actions in a logical form in accordance with the process of creating an Entrepreneurial University. As a self-assessment tool, it helps individual universities to identify and assess their own strengths and weaknesses in their current situation and plan potential improvement actions, taking into account their local, national and international environments. Unfortunately, the OECD framework cannot be considered as a benchmarking tool, because the proposed statements are individual and contextual, there is no operationalization of the terms, hence the measurement 
methods and outcomes may have many limitations and ambiguities. Undoubted usefulness of the Guiding Framework for Entrepreneurial Universities lies in the possibility to elaborate joint discussion within and among the organization(s) that is needed to gain joint understanding from all the relevant partners.

\section{Challenges for Operationalisation and Measurement}

Due to the wide scope of Entrepreneurial University characteristics, the present research study is limited and focuses on the endo- and exogenous factors affecting the creation or rather the transformation and development into an Entrepreneurial University embedded in an entrepreneurial business ecosystem. Due to the fact that universities operate in specific socio-economic and cultural conditions, in a specific business environment, the research approaches and outcomes are ambiguous and therefore difficult to make objective comparisons and assessments.

The OECD ${ }^{41}$ Entrepreneurial University framework may well serve as a starting point to examine the level of entrepreneurship in various areas of the university's activity and compare it with the developed statements to assess the current situation. The areas where improvement is considered a priority could then be worked on. However, to get a high or low rating the associated performance indicators are crucial. Unfortunately, as mentioned before, many proposed statements/factors (especially informal ones such as traditions and reputation) are individual and contextual, hence it is difficult to assess them objectively to get reliable results (for example, the entrepreneurial agenda is usually tailor made to the individual purposes). There are many "soft" areas and invisible university resources that are difficult to be operationalized and measured by quantitative methods. For example, how to make an objective assessment of the following statements: (i) staff take an entrepreneurial approach to teaching and learning in all departments, promoting diversity; (ii) the institution uses entrepreneurial attitudes, behaviours and experience as criteria in the recruitment process; (iii) there are clear incentives and rewards for staff who actively support the university's entrepreneurial agenda.

Further measurement problems concern: (i) the extent of collaboration and knowledge exchange with universities and the external stakeholders; (ii) the scope of cooperation and contact between new entrepreneurs, universities and local governments, and their attitudes to preserving the environment; (iii) the level of staff engagement in entrepreneurial teaching and learning across the institution; (iv) generating

41 Ibidem. 
of entrepreneurial motivation, cognition, and attitudes; (v) generating entrepreneurial competences and skills; (vi) the impact of support services on the success of the academic start-ups; (vii) and especially, comparison and contrasting the findings. For these reasons, decision makers must be very careful when making recommendations and creating policies towards an Entrepreneurial University.

The evidence reveals a tendency to use case studies to explore and build understanding on the phenomenon of the Entrepreneurial University ${ }^{42}$. Possible reasons are related to a large range and variety of characteristics of this issue, a lack of one universally recognized method and indicators for measuring this phenomenon, a large number of variables depending on the economic, social, governmental and business environment as well as many qualitative factors. To design policies that will stimulate the entrepreneurial activity of universities and their contribution to the development of the modern knowledge economy and sustainable environment is now a major challenge.

\section{Conclusions}

The Entrepreneurial University framework and the preconditions for its transformation developed in this study are a theoretical approximation related to the endo- and exogenous factors within the entrepreneurial ecosystem which are crucial to making the university more entrepreneurial. However, an empirical analysis and specific measurement indicators are required. Although the concept has received considerable attention over the previous years, further comparative studies and a consideration of the practical aspects of its implementation and impact are expected in order to create a measurement apparatus which is as coherent and as widely recognized conceptually as possible.

It is now generally accepted that Entrepreneurial Universities are an essential instrument in the facilitation of technology transfer, knowledge spillover and startup creation. Furthermore, they are considered as important accelerators for regional, economic and social development. For these reasons, it is necessary to establish supporting measures to create favourable environments for entrepreneurship at the

42 B.R. Clark, Creating Entrepreneurial Universities...; B. Sporn, Building Adaptive Universities...; A. Gibb, G. Haskins, I. Robertson, Leading the Entrepreneurial University...; T. Aldridge, D.B. Audretsch, The Bayh-Dole Act and Scientist Entrepreneurship, "Research Policy" 2011, vol. 40(8), pp. 1058-1067; D.A. Kirby, M. Guerrero, D. Urbano, Making Universities More Entrepreneurial: Development of a Model, "Canadian Journal of Administrative Sciences" 2011, vol. 28, pp. 302-316; D. Urbano, M. Guerrero, Entrepreneurial universities: Socio-economic impacts of academic entrepreneurship in a European region, "Economic Development Quarterly" 2013, vol. 27(1), pp. 40-55; D. Arnaut, R. Dogić, The Inevitability...; L. Timonen, E. Badzinska, H. Immonen, How to build entrepreneurial pathways... 
university level. Nowadays, a common response to the demands of stakeholders is a strategy which is oriented to promoting the entrepreneurial mindset by reforming the curricula so as to provide academic graduates with more practical skills, and to be more multi-disciplinary and social competent in order to discover entrepreneurial opportunities and to boost employability.

Universities should be active players, linked to their external environment by having a strong presence in the community. This might include for example, providing opportunities for regional start-ups or established companies, participating in regional clusters and taking an active role in determining the strategic direction of local development ${ }^{43}$.

Building and sustaining business-science relationships with key partners, stakeholders and collaborators is essential in achieving the full potential of an Entrepreneurial University in research, teaching and entrepreneurship mission activities. The motivation for this commitment is to create value for the university and society. Therefore, developing university-based entrepreneurial practices are considered as a significant contribution in supporting the strategic development of education and research, bridging universities with their entrepreneurial ecosystem in a meaningful way.

To obtain a deeper insight into the research problem, the future investigation will focus on the identification of critical factors related to the transformation process to an Entrepreneurial University using multiple case studies. The process of translating the factors defined in the conceptualisation process into measurable indicators will be necessary.

\section{References}

Aldridge T., Audretsch D.B., The Bayh-Dole Act and Scientist Entrepreneurship, "Research Policy" 2011, vol. 40(8), pp. 1058-1067.

Antoncic B., Hisrich R., Intrapreneurship: Construct refinement and cross-cultural validation, "Journal of Business Venturing" 2001, vol. 16, pp. 495-527.

Arnaut D., Dogić R., The Inevitability of University Entrepreneurial Path, [in:] V. Babić (ed.), Contemporary Issues in Economics Business and Management, Faculty of Economics University of Kragujevac, Kragujevac 2018, pp. 69-80.

Audretsch D.B., From the entrepreneurial university to the university for the entrepreneurial society, "The Journal of Technology Transfer" 2014, vol. 39, pp. 313-321.

Badzińska E., The Concept of Technological Entrepreneurship: The Example of Business Implementation, "Entrepreneurial Business and Economics Review" 2016, vol. 4(3), pp. 55-70.

43 OECD, A Guiding Framework... 
Badzińska E., Timonen L., Entrepreneurial Mindset and Muliticultural Communication Skills: a Reflection on the ECMT+ Intensive Programme, "Zeszyty Naukowe Politechniki Poznańskiej", serie "Organizacja i Zarządzanie" 2019, no. 79, pp. 5-19.

Clark B.R., Creating Entrepreneurial Universities. Organisational pathways of transformation, Pergamon IAU Press, Oxford 1998.

Clark B.R., Sustaining Change in Universities: Continuities in case studies and concepts, Society for Research into Higher Education and Open University Press, New York 2004.

Clark B.R., The Higher Education System: Academic Organisation in Cross-national Perspective, University of California Press, Berkeley 1983.

Drucker P.F., Innovation and Entrepreneurship, Harper and Row, New York 1985.

Etzkowitz H., Entrepreneurial Scientists and Entrepreneurial Universities in American Academic Science, "Minerva" 1983, vol. 21(2-3), pp. 198-233.

Etzkowitz H., Research groups as 'quasi firms': the invention of the entrepreneurial university, "Research Policy” 2003, vol. 32, pp. 109-121.

Etzkowitz H., The evolution of the entrepreneurial University, "International Journal of Technology and Globalisation" 2004, vol. 1(1), pp. 64-77.

Etzkowitz H., Leydesdorff L., The dynamics of innovation: from the National Systems and "Mode 2" to a Triple Helix of university-industry-government relations, "Research Policy" 2000, vol. 29, pp. 109-123.

Etzkowitz H., Webster A., Gebhardt C., Brance R., Cantisano T., The future of the University and the University of the future: Evolution of ivory tower to entrepreneurial paradigm, "Research Policy" 2000, vol. 29(2), pp. 313-330.

Fayolle A., Gailly B., The Impact of Entrepreneurship Education on Entrepreneurial Attitudes and Intention: Hysteresis and Persistence, "Journal of Small Business Management" 2015, vol. 53, pp. 75-93.

Gibb A., Towards the Entrepreneurial University. Entrepreneurship Education as a lever for change, NCGE UK Policy Paper series, 2005.

Gibb A., Haskins G., Robertson I., Leading the Entrepreneurial University. Meeting the entrepreneurial development needs of higher education institutions, NCGE UK, Birmingham 2009.

Guerrero M., Urbano D., The Creation and Development of Entrepreneurial Universities in Spain: An Institutional Approach, Nova Publishers, New York 2011.

Guerrero-Cano M., Kirby D., Urbano D., A literature review on entrepreneurial universities: An institutional approach, Working paper presented at the 3rd Conference of Pre-communications to Congresses, Business Economic Department, Autonomous University of Barcelona, Barcelona, June 2006.

Guzmán J., Liñán F., Perspectives on Entrepreneurial Education: A US Europe Comparison, Universidad Antionio de Nebrija, Madrid 2005.

Kirby D.A., Creating Entrepreneurial Universities: A Consideration, Working Paper, School of Management, University of Surrey, 2002.

Kirby D.A., Creating Entrepreneurial Universities in the UK: Applying entrepreneurship theory to practice, "Journal of Technology Transfer" 2006, vol. 31(5), pp. 599-603.

Kirby D.A., Guerrero M., Urbano D., Making Universities More Entrepreneurial: Development of a Model, "Canadian Journal of Administrative Sciences" 2011, vol. 28, pp. 302-316.

Kurek S., Rachwat T., The Role of Business Education in the Development of Entrepreneurship in the Member States of the European Union, "Europa XXI" 2010, vol. 19, pp. 127-142.

McAdam M., Miller K., McAdam R., University business models in disequilibrium - engaging industry and end users within university technology transfer processes, "R\&D Management" 2017, vol. 47(13), pp. 458-472. 
OECD, A Guiding Framework for Entrepreneurial Universities, 2012, https://www.oecd.org /site/cfecpr/EC-OECD\%20Entrepreneurial\%20Universities\%20Framework.pdf (accessed: 18.10.2019).

Rachwał T., Kurek S., Boguś M., Entrepreneurship Education at Secondary Level in Transition Economies: A Case of Poland, "Entrepreneurial Business and Economics Review" 2016, vol. 4(1), pp. 61-81.

Raposo M., Paço A., Entrepreneurship Education: Relationship between Education and Entrepreneurial Activity, "Psicothema" 2011, vol. 23(3), pp. 453-457.

Sporn B., Building Adaptive Universities: Emerging Organisational Forms Based on Experiences of European and US Universities, "Tertiary Education and Management" 2001, vol. 7(2), pp. 121-134.

Timonen L., Badzinska E., Immonen H., How to build entrepreneurial pathways for students? - Reflections on development cases from Karelia University of Applied Sciences, Finland, and Poznan University of Technology, Poland, Working Paper, International Conference CREE2019 Entrepreneurship Education, Roanne, March 2019, pp. 1-14.

Urbano D., Guerrero M., Entrepreneurial universities: Socio-economic impacts of academic entrepreneurship in a European region, "Economic Development Quarterly" 2013, vol. 27(1), pp. 40-55.

Van Vught F., Innovative Universities, "Tertiary Education and Management" 1999, vol. 5(4), pp. 347-354.

Wach K., Entrepreneurship Education in Poland, "ERENET Profile" 2008, vol. III, no. 3(11), pp. 36-44. Wach K., Europeanisation of Entrepreneurship Education in Europe - Looking Back and Looking Forward, "Horyzonty Wychowania" 2014, vol. 13(26), pp. 11-31.

Żur A., Exploring the Role of Inspiration in Entrepreneurship Education, "Horyzonty Wychowania" 2014, vol. 13(26), pp. 179-194.

Abstract

There is a growing global need for entrepreneurs from technological, social, cultural and economic backgrounds to launch new ventures and engage in innovative business activities. Significant challenges in economy and society, industrial development 4.0 and international cooperation pathways have all shed new light and made new demands on higher education systems across the world. Universities need to ensure new ways of learning and teaching, greater practical usefulness of scientific research findings and cooperate widely with the entrepreneurial ecosystem to be able to renew their curricula and practices for boosting employability and to improve career opportunities for academic graduates.

The explorative qualitative study focuses on the university-based entrepreneurial activities and the business ecosystem. The purpose of the study is to review the approaches of scholars and present a discussion on the theoretical framework concerning the Entrepreneurial University. It is an attempt to adapt existing models and bring new factors together with current reflections on this phenomenon. The contribution of the author consists of developing a framework of preconditions - endo- and exogenous factors within the entrepreneurial ecosystem and micro- and macroeconomic environment - necessary to transform a traditional university into an entrepreneurial one. Building and sustaining business-science relationships with key partners, stakeholders and collaborators seems to be essential in achieving the full potential of an Entrepreneurial University in research, teaching and entrepreneurship mission activities. The author identifies the limitations, ambiguities and difficulties with the operationalisation of significant factors, variables and their measurement. 
The nature of the study is descriptive, and the methods used in this objective are a critical review of the subject literature, defining, comparing, analysis, reflection, and inference. The paper concludes with recommendations and directions for an in-depth empirical research. In order to obtain a deeper insight into the research problem the future investigation will focus on the identification of critical factors related to the transformation process into an Entrepreneurial University using multiple case studies. Although the concept has received considerable attention over the last years, further comparative studies of the practical aspects of its implementation and impact are expected to create a coherent and widely recognized conceptual and measurement apparatus.

Keywords: business-science relationships, entrepreneurial ecosystem, entrepreneurial university, entrepreneurship, higher education 